\title{
PERSPECTIVITY OF USING STRUCTURAL INSULATED 3D PANELS IN THE CONSTRUCTION ON ENERGY EFFICIENT BUILDINGS AND STRUCTURES
}

\author{
${ }^{1}$ Dudar I.N., Doctor of Technical Sciences, Professor, \\ indudar11@gmail.com, ORCID: 0000-0001-8453-7929 \\ ${ }^{1}$ Yavorovska O.V., post-graduate student, \\ olhaiavorov@gmail.com, ORCID: 0000-0002-5304-1389 \\ ${ }^{1}$ Vinnytsia National Technical University \\ 95, Khmelnytske Shosse str., Vinnytsia, 21021, Ukraine
}

\begin{abstract}
The problem of energy dependence has been acute for all sectors of the national economy since the beginning of Ukraine's independence. At the same time, special attention is paid to the issues of energy saving in construction and urban economy, as cities use more than $85 \%$ of energy resources. The current situation is a consequence of the deformed structure of energy consumption, the use of outdated technologies in utilities, the slow implementation of energysaving measures and technologies, and the lack of proper modernization of buildings and structures.

Therefore, today the issue of researching building materials that would be energy-saving, primarily due to sealing and thermal insulation, is relevant. One of these building products is a composite building material - 3D structural insulating panel (SIP).
\end{abstract}

The article substantiates the possibility to using modern structural insulated panels in building. The main technical characteristics and features of the device of 3D panels are highlighted, indicators are given that confirm the relevance of this technology use in combination with the use of recuperators in construction. The basic structure of SIP panels is described in detail. The advantages and disadvantages of existing structural insulated panels are shown, both from the point of view of energy saving and from the point of view of the peculiarities of their use in general.

It is calculated that the use of a SIP makes it possible to reduce the cost of construction in 2 times. For example, the cost of $1 \mathrm{~m}^{2}$ of the total area of the house is from $\$ 80$, and when fully finished, it can be $\$ 300$ per $\mathrm{m}^{2}$. At the same time, due to the high technical characteristics of the insulation, energy consumption for heating is significantly reduced.

As a result of the study, it was proved that the use of SIP technology is a profitable solution, as it has a positive effect on the energy efficiency of a building due to its inherent design features. The relevance of the installation of these panels is confirmed by the fact that buildings, regardless of their purpose, have savings in energy costs in the amount of $65-70 \%$.

Keywords: energy efficiency, fuel and energy resources, structural insulating panel, 3D panels, recuperator.

Introduction. The issue of energy efficiency has been acute for all sectors of the national economy since the beginning of Ukraine's independence. Thus, to address this issue in 2005, the National Agency on Efficient Use of Energy Resources of Ukraine was established, and later - the State Agency on Energy Efficiency and Energy Saving of Ukraine. Since 2015, a number of regulations on energy saving have been adopted, which are based on the goal of implementing Directive 2012/27 / EU of 25 October 2012 on energy efficiency [1].

Particular attention is paid to energy conservation in construction and municipal economy of the city, because it is at the city as a result of accounting for over $85 \%$ of energy [3, p. 15], [4, p. 21].

However, it should be noted that the main problem in our country is not a shortage of natural energy resources. Ukraine has reserves of its own fuel and energy resources (FER) about 45\%, which is one of the highest indicators of energy self-sufficiency among the countries of the world. The problem is the low efficiency of using fuel and energy resources. Energy intensity Gross Domestic Product (GDP) in Ukraine is several times higher than in developed countries. Today, the energy intensity of GDP in Ukraine is at the level of $0.93 \mathrm{~kg}$ of fuel equivalent/USD, which is twice 
as much as the world average $-0.39 \mathrm{~kg}$ of fuel equivalent/USD. This trend can be traced in all spheres of the Ukrainian economy. In the housing and utilities sector, the expenditure of fuel and energy resources per $1 \mathrm{~m}^{3}$ of water, per $1 \mathrm{~m}^{2}$ of the total area of residential buildings significantly exceeds the world standards, which indicates a low level of energy saving [5, p. 106 - 107].

The current situation is a consequence of the misrepresented structure of energy consumption, the use of outdated technologies on communal services, the slow implementation of energy-saving measures and technologies, and the lack of proper modernization of buildings and structures.

Therefore, today the issue of researching building materials that were energy-saving is relevant today, primarily due to sealing and thermal insulation. One example of such building products is a composite construction material, namely a structural insulated panel (SIP).

Analysis of recent researches and publications. SIPs have long been used in residential and public buildings. The first forms of sandwich panels were developed at the end of World War II. Historically, the appearance of panels is associated with a shortage of building materials and an acute shortage of facing materials [15]. The first panels had cellulose filling, and their "covering" was plywood or veneer. The idea of creating a structural insulation panel originated in 1935 in the Laboratory of Forest Products (FPL) in Madison, Wisconsin, USA [14, p. 2 - 4]. FPL researchers have found that fiberboard and plywood cladding can carry a fairly high load. The first commercial panel was released by Dow in 1952 [14, p. 3].

Although SIP is a well-known product, however, in recent years, the demand for it has grown significantly not only in Ukraine, but throughout the world [10, p. 37 - 40]. The increase in popularity is the result of many different reasons, including the high heat capacity of the panels and the simplicity of its design.

As fuel prices rose, the use of these panels in new construction is relevant, since modern SIP is able to reduce heat losses by $40-60 \%$ [11]. According to Insulspan, $10 \mathrm{~cm}$ thick SIP has a thermal resistance of 3.83, which is at least $25 \%$ higher than the indicator of a high-quality insulated brick wall. The thermal insulation advantages SIP are noted by a number of scientists Little J.C., Kumar D., Cox S.S., Hodgson A.T. [13], Smith R.E. [16], Kim D.G.[12].

Another advantage of the material is fast mounting. Construction time using SIP is much shorter than traditional construction. A study by Anosike and Oyebade [10, p. 37 - 40] shows that the use of SIP reduces labour intensity by $60 \%$, which reduces construction time. SIPs are easy to install, since they come to the construction site with an almost finished structure. The individual panels are connected and assembled only with a veneer sheets. Manufacturers and SIP contractors use different designs and different types of compounds that affect the design and speed of installation panel strength.

SIP as a promising material for construction was studied by Voloshin M.M. [2], Komelina A.V. [6], Melnichuk N.V. [7].

The wide interest in SIP today, in turn, gives rise to a number of problematic issues - how effective and safe are SIP during the cold season, during construction in seismic regions, etc. Unfortunately, the problem of the practical application of SIP in scientific articles is not fully covered. There is only a little research conducted by manufacturers. However, such studies cannot show the full depth of the issue and the real problems. Therefore, there is an urgent need for further research of the problem of SIP operation in housing construction.

The aim of this work is the realization of forward-looking assessment of the SIP use in housing to save energy.

Materials and methods of research. For comprehensive analysis of the feasibility of using modern structural insulated panels in housing construction, we used the method of generalization, a systematic approach and statistical analysis to find the relationship between the technical, physical and economic characteristics of the material.

Research results. Improving energy efficiency in the residential sector is possible by creating energy efficient residential buildings (new construction) and by increasing the energy efficiency of the existing housing stock (reconstruction) [6, p. 108]. 
There is one of the modern technologies for the construction of energy-efficient buildings and structures using three-layer reinforced panels of the so-called SIP panels (Fig. 1) has shown in article.

SIP panels consist of reinforced mesh of stainless or galvanized rods and a core of insulating material (polystyrene, mineral, basalt and other insulation) and two layers of concrete, applied by shotcreting. Such panels are called SIPs and they are the most energy efficient material in the world.

The technology for the construction of houses from SIP is based on the method of monolithic construction, which means that the walls and supporting structures are brought together using reinforced panels and represent a single monolithic structure [9].

The material of the reinforced panels made in factory conditions consists of a reinforced frame with the warmed core from heat-insulating material, but without the concrete on its surface. Concrete is applied to the mounted reinforced panel and it gives bearing capacity to a design.

Additional strength of panels design is given with cross diagonal rods which are welded to a reinforcing grid from all parties with a certain inclination. After installation of such panels on two parties concrete "B20" are applied, by a method of shotcreting approximately $5 \mathrm{~cm}$ thick, without use of timberings that considerably reduces labor intensity of the building construction.

The total thickness of the finished wall can be $22 \mathrm{~cm}$. With this thickness, the panels provide sound and thermal insulation, which is equal to a brick wall 1.5 meters thick.

A feature of the shotcrete method is the application of a mixture of cement, sand and water. Using a hose, it is applied to the wall surface at high speed and under pressure. By applying under pressure, the mixture is compacted; at the same time, the physical and mechanical properties of concrete applied by shotcrete significantly exceed the properties of, for example, ordinary concrete [9].

SIP with concrete casing is a reliable monolithic construction. Concrete gives the structure an increased load-bearing capacity and is applied to the mounted reinforced-panel. Built house with SIP using expanded polystyrene, fairly environmentally friendly and comfortable housing.

The heat-insulating properties of the material are interesting for research. When the positive temperature rises inside the building, an overpressure of up to $150 \mathrm{~Pa}$ is created and the air from the inside "tends" to come out. This is facilitated by the increased penetration of walls from SIP panels, which is more than $580 \mathrm{~m}^{3}$ per hour. For comparison, with a wooden house, this characteristic is much less and amounts to $10 \mathrm{~m}^{3}$ per hour [9].

The general view of SIP 3D is presented in Fig. 1.

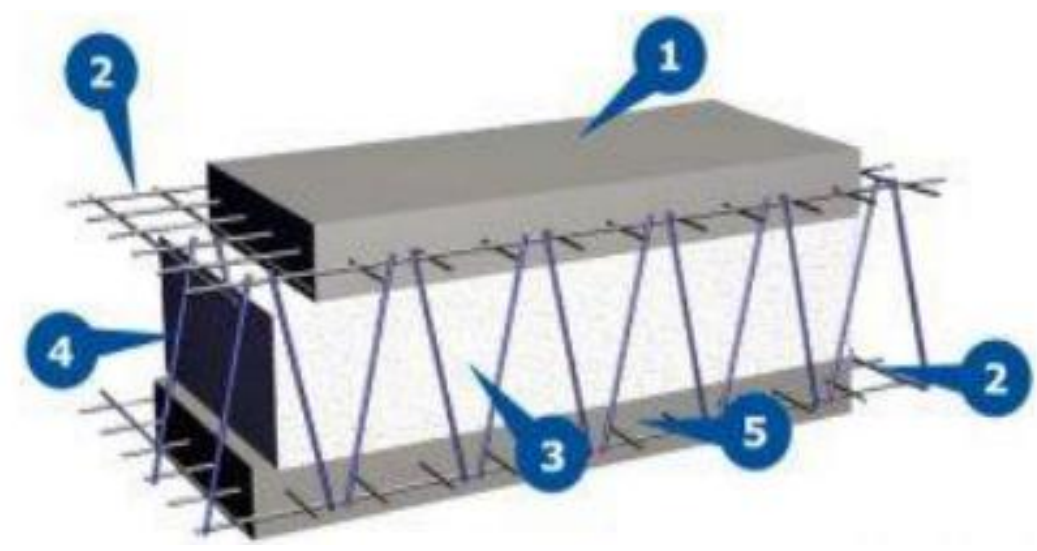

Fig. 1. SIP panel in section:

1 - outer concrete layer; 2 - welded reinforcing mesh; 3 - expanded polystyrene core; 4 - diagonal made of stainless or galvanized wire; 5 - inner layer of concrete [9]

In addition to foamed polystyrene, mineral wool, glass wool and other modern heaters can be used as a heat-insulating material. Reinforcing mesh is made from wire $\mathrm{d}=2.5-3.0 \mathrm{~mm}$, mesh size is 5 by $5 \mathrm{~cm}$, diagonal rods are made of galvanized or stainless wire with a diameter of 3-4 mm.

Concrete for SIP coating is fine-grained concrete, class above B20. Construction of houses from SIP panels is carried out now according to DBN 15.886 - 86. SIP panels are used to make capital walls, interior partitions, roofs, fencing, stairs and other building structures [9]. 
Technology of buildings erection from SIP panels. The installation of the house walls begins with the installation of SIP panels on the foundation, which can be a monolithic slab. Then reinforcing rods are installed on the foundation, on which SIP panels are attached with a standard size of 3 by 1.5 or 3 by $1.2 \mathrm{~m}$. Waterproofing is arranged along the perimeter of the installation of the panels, at the points of connection to the foundation. The panels are manually fastened to the reinforcement rods in turn with the aid of a wire, adjusting them vertically and horizontally.

The SIPs are interconnected by fragments of a reinforcing mesh, creating a continuous reinforced frame with insulation inside. When the panels, walls and ceilings have been installed and all the necessary communications have been laid, the reinforced insulation is carried out (gunning the frame made of reinforced insulation on both sides). At this stage, the structure of the house acquires a bearing capacity. After that, the walls and ceilings are ready for plastering and painting.

All communications provided by the project: heating, plumbing, water disposal, power supply are laid inside the SIP panels. Engineering networks are laid in an open way, outside the building.

The advantages of the construction on modern energy efficient buildings and structures. The construction of buildings from SIP panels has significant advantages, the main of which are: high speed of construction, energy efficiency of the structure, cost savings on construction and installation work.

The use of SIP allows to reduce the cost of construction by 2 times. For example, the cost of $1 \mathrm{~m}^{2}$

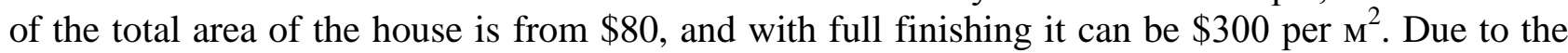
high technical characteristics of the insulation, energy consumption for heating is significantly reduced.

Due to the use of extrusive polystyrene, which is practically inert, there is an increase in the service life, as the material practically does not absorb moisture, it is resistant to decay. At the same time, the construction of the walls is highly gas-permeable, however, it prevents the penetration of moisture into the room.

The quantitative advantages of SIP 3D in comparison with more traditional materials - gas blocks and insulated bricks are given in Table 1.

Table 1 - Comparison of the cost of $1 \mathrm{~m}^{2}$ of building wall of different materials

\begin{tabular}{|c|c|c|c|c|}
\hline Characterization & CI & SIP 3D & Gas block & $\begin{array}{l}\text { Brick with } \\
\text { insulation }\end{array}$ \\
\hline Thermal conductivity & $\mathrm{kV} / \mathrm{m}^{2}$ & 3,72 & 3,30 & 3,12 \\
\hline Wall thickness & $\mathrm{mm}$ & 220 & 370 & 500 \\
\hline Weight $1 \mathrm{~m}^{2}$ & $\mathrm{~kg}$ & $200-250$ & $250-300$ & $600-650$ \\
\hline Price of $1 \mathrm{~m}^{2}$ of wall & grn. & 800 & $1325^{*}$ & $1733^{*}$ \\
\hline Amount of material & pc. & 3 & 7 & 11 \\
\hline Multitude of processes & pc. & 3 & 5 & 4 \\
\hline Number of specialists & ps. & 4 & 10 & 10 \\
\hline Time of construction & month. & $1,5-2$ & $4-5$ & over 6 \\
\hline $\begin{array}{l}\text { Price of } \mathrm{m}^{2} \text { house with } \\
\text { decoration }\end{array}$ & $\$$ & over 100 & over 400 & over 500 \\
\hline
\end{tabular}

SIP panels have high thermal insulation rates. Heating and ventilation costs are reduced in as much as $3-6$ times and do not exceed $0.05-0.06 \mathrm{~J}$ for residential buildings $\left(13.9-13.7 \mathrm{~kW}\right.$ per $1 \mathrm{~m}^{2}$ per year). The construction of a standard cottage with an area of $100 \mathrm{~m}^{2}$ saves free space, for example, up to $12 \mathrm{~m}^{2}$ compared to brick walls. Such houses can be erected in areas with weak soils, sandy foundations, and they can withstand earthquakes up to 9 on the Richter scale.

Installation SIP does not depend on weather conditions. Construction can be carried out at temperatures down to $-15^{\circ} \mathrm{C}$. It is possible to design various architectural facades and use flexible technology. A fairly high rate of construction of such houses. So, a team of 4 people can build a 
monolithic three-story building with an area of $200 \mathrm{~m}^{2}$ in 30 days. The insignificant weight of the SIP makes it possible to abandon construction cranes and heavy construction equipment, while the load on the foundations is significantly reduced and the requirements for the bearing capacity of the foundations are reduced.

In addition to the increased strength and high energy efficiency, it should be noted that the walls are well soundproofed, it improves the ecology of citizens' life in multi-storey buildings and near a noisy highway. If the thickness of the panel is $22 \mathrm{~mm}$, then the coefficient of heat and sound insulation is the same as for a brick wall with a thickness of $1.3 \mathrm{~m}$. It is possible to use $3 \mathrm{D}$ panels for the construction of soundproof walls in buildings.

Houses built from SIP panels can be easily heated with solar systems, heat pumps or use heat from the depths of the earth, as well as electricity at a low cost of $15 \mathrm{~W} / \mathrm{h}$ per $\mathrm{m}^{2}$ at a minimum temperature of $-40^{\circ} \mathrm{C}$

To improve air exchange in such houses, you can use heat-saving ventilation based on recuperates. Such a system creates natural freshness in rooms and stabilizes the microclimate. At the same time, energy savings are created through recuperation.

The recuperator supplies fresh outside air, removing high $\mathrm{CO}_{2}$ content, without the need to open windows and waste heat. Due to the lack of moisture in the room, the recuperator protects the house from mould and mildew, fogging of windows. The recuperator can be easily operated using a remote control. The use of such devices allows you to remove from the room air that is contaminated with microparticles of dust, smoke and provides an influx of fresh air from outside. At the same time, the supply and exhaust air passes through different channels and does not mix in volume during ventilation. There is an interchannel heat transfer, which ensures the system's energy efficiency at any time of the year.

Due to the innovative design, the recuperator efficiency reaches 92\%. Using such a recuperator, it is possible to increase the overpressure by $10 \%$ and start ventilation in the premises. The recuperator has an additional external air heater, a condensate drain, it can work in night mode, while it creates minimal noise and energy consumption. The ventilation volume is $25 \mathrm{~m}^{3}$ per hour. The technical characteristics of a recuperator with a diameter of $200 \mathrm{~mm}$ are as follows: the recommended area for ventilation is up to $60 \mathrm{~m}^{2}$, the power consumption is from 6 to $30 \mathrm{~W}$ per hour. Air exchange, tide, exhaust air is at the level of $135-125 \mathrm{~m}^{3}$.

The operating principle of the recuperator is shown in Fig. 2.

Thus, the use of SIP 3D, in addition to energy-saving quality, has a number of advantages:

- Low labor-intensive installation. The SIP is installed on a finished foundation without the use of heavy equipment at any time of the year by a team of 4 people, that is, several times faster than with traditional brick construction. The interior and exterior surfaces of the building are smooth and ready for any kind of finish, which further reduces construction time.

- Ergonomic advantage. Due to the thinner walls with high thermal resistance, we obtain up to $10 \%$ additional usable interior space.

- Reduced costs during the construction phase: SIPs and their installation are cheaper than traditional construction.

- Reducing costs at the stage of building operation: SIPs have a high thermal performance they retain heat in winter, and in summer they retain the effect of night cooling. Therefore, there is a possibility of saving on the air conditioning system.

- Durability. Structures made of SIP panels have unique properties: they are not susceptible to moisture absorption and decay; withstand hurricane winds and earthquakes up to 8 points. The estimated life of houses with SIP is more than 100 years.

- Environmental friendliness. SIP is a building material that meets modern living space requirements. 


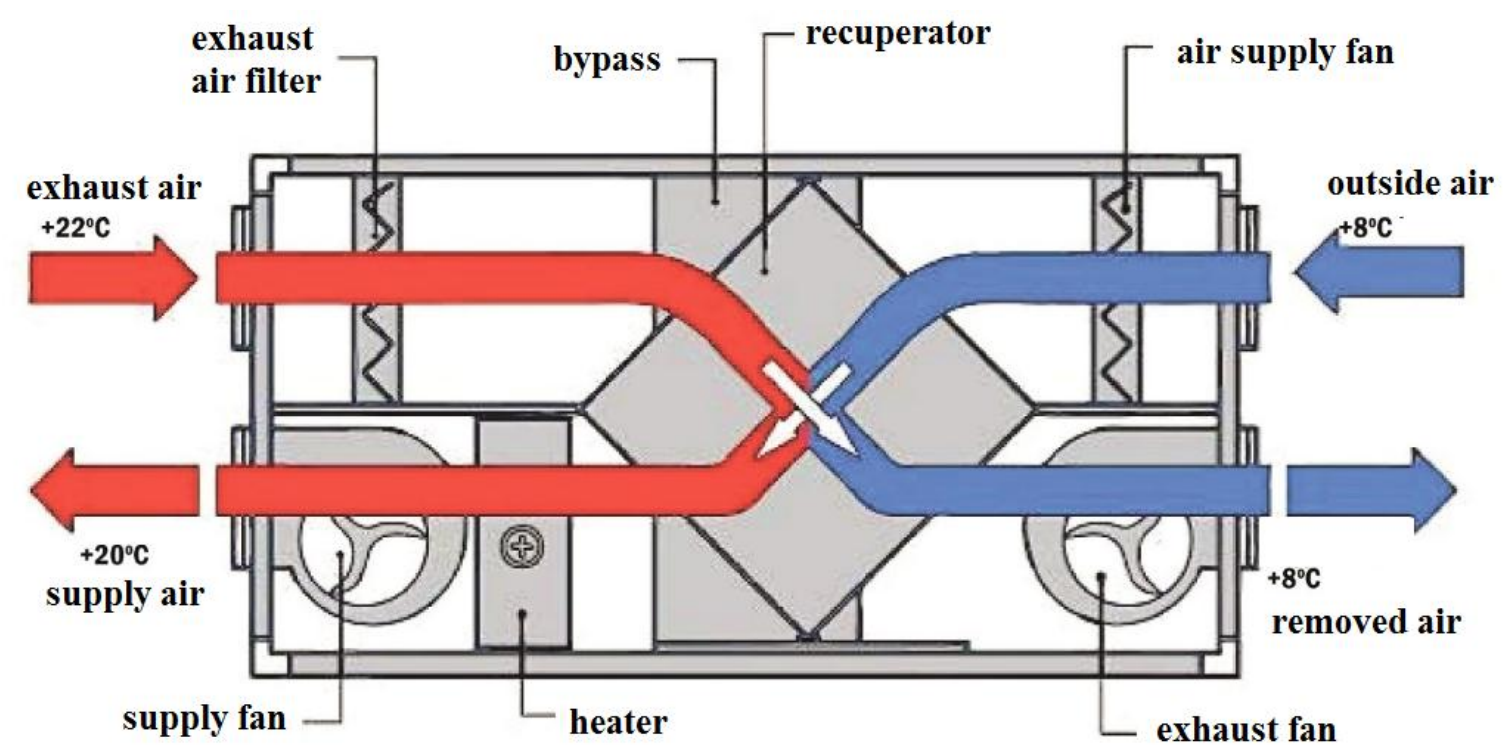

Fig. 2. The operation principle of the recuperator [8]

Conclusions. As a result of research, we can conclude that the use of SIP panel technology is a profitable solution, because it make a positive effect on the energy efficiency of the building due to the design features. The relevance of using these panels is confirmed by the fact that buildings, regardless of purpose, have energy savings of $65-70 \%$.

\section{References}

[1] Vykonannia zoboviazan Ukrainy v ramkakh Protokolu pro pryiednannia do Dohovoru pro zasnuvannia Enerhetychnoho Spivtovarystva. [Online]. Available: https://saee.gov.ua/uk/activity/mizhnarodne-spivrobitnytstvo/eu-integration. Accessed on: August 05, 2020.

[2] M.M. Voloshyn, "Budivnytstvo enerhozberihaiuchoho budynku - dosvid ES", «Budivelni materialy, konstruktsii ta sporudy tretoho tysiacholittia»: mat-ly vseuk. nauk.-prakt. konf. Kherson, «Khersonskyi derzhavnyi ahrarnyi universytet», 2019, pp. 45-49.

[3] I.N. Dudar, L.V. Kucherenko, V.V. Shvets, Enerhozberezhennia v miskomu budivnytstvi. Chastyna 1: navch.posib. Vinnytsia : VNTU. 2018.

[4] I.N. Dudar, L.V. Kucherenko, V.V. Shvets, Enerhozberezhennia v miskomu budivnytstvi. Chastyna 2: navch.posib. Vinnytsia : VNTU. 2018.

[5] I.N. Dudar., O.V. Yavorovska, "Analiz metodiv otrymannia alternatyvnoi enerhii u zhytlovo - komunalnomu sektori", Suchasni tekhnolohii, materialy $i$ konstruktsii $v$ budivnytstvi, vol. 1, pp. 105-109, 2014.

[6] O.V. Komelina., S.A. Shcherbinina, "Suchasni problemy zabezpechennia enerhoefektyvnosti zhytlovoho budivnytstva v Ukraini", Ekonomika ta upravlinnia natsionalnym hospodarstvom, vol. 3, pp.108-114, 2014.

[7] N.V. Melnychuk, "Osoblyvosti budynkiv pobudovanykh za SIP-tekhnolohiieiu", Mistobuduvannia ta terytorialne planuvannia, vol. 40(2), pp.39-44, 2011.

[8] Rekuperatori prana - ofytsyalii tsentr prodazh. [Online]. Available: https://prana.com.ua/. Accessed on: August 05, 2020.

[9] Tekhnolohyia stroytelstva. [Online]. Available: https://3dpanel.com.ua, Accessed on: August 05, 2020.

[10] M. N. Anosike, A. A. Oyebade, "Sandcrete Blocks and Quality Management in Nigeria Building Industry", Journal of Engineering, Project, and Production Management, vol. 2, pp. 37-46, 2011. 
[11] Insulspan, the industry leader in structural insulated panels. [Online]. Available: https://www.insulspan.com/. Accessed on: August 05, 2020.

[12] B.J. Kim, D.G. Lee, "Characteristics of joining inserts for composite sandwich panels", Composite Structures, vol. 86, pp.55-60, 2008.

[13] J.C. Little, D. Kumar, S.S. Cox, A.T. Hodgson, Barrier materials to reduce contaminant emissions from structural insulated panels. Advances in Building Technology. Oxford: Elsevier, 2002.

[14] M. Panjehpour, A. Ali, Y. Voo, "Structural Insulated Panels: Past, Present, and Future", Journal of Engineering, Project, and Production Management, vol. 3(1), pp. 2-8, 2013.

[15] M.V. Savytskyi, V.V. Danishevskyi., M.M. Babenko, Ye.L. Yurchenko, "Study of shell for energy efficient of sustainable low-rise building", Visnyk Prydniprovskoi derzhavnoi akademii budivnytstva ta arkhitektury, vol. 3 (216), pp.10-17, 2016.

[16] R. E. Smith, Prefab Architecture: A Guide to Modular Design and Construction. John Wiley and Sons, 2011.

\title{
ПЕРСПЕКТИВНІСТЬ ВИКОРИСТАННЯ СТРУКТУРНИХ ІЗОЛЬОВАНИХ ПАНЕЛЕЙ ЗD ПРИ ЗВЕДЕННІ ЕНЕРГОЕКОНОМІЧНИХ БУДІВЕЛЬ І СПОРУД
}

\author{
${ }^{1}$ Дудар І.Н., д.т.н., професор, \\ indudar11@gmail.com, ORCID: 0000-0001-8453-7929 \\ ${ }^{1}$ Яворовська О.В., здобувач, \\ olhaiavorov@gmail.com, ORCID: 0000-0002-5304-1389 \\ ${ }^{1}$ Вінницький національний технічний університет \\ вул. Хмельницьке шосе, 95, м. Вінниця, 21021, Україна
}

Анотація. Питання енергетичної ефективності стоїть гостро для всіх галузей народного господарства ще 3 початку здобуття Україною незалежності. При цьому особливу увагу приділено питанням енергозбереження в будівництві та комунальному господарстві міста, оскільки саме на міста припадає більше 85\% енергоресурсів. Ситуація, що склалася $\epsilon$ наслідком деформованої структури енергоспоживання, використання застарілих технологій в комунальному господарстві, повільного впровадження енергозберігаючих заходів i технологій, а також відсутності належної модернізації будівель і споруд.

Тому, сьогодні актуальним є питання дослідження будівельних матеріалів, які були б енергозберігаючими, в першу чергу за рахунок герметизації і теплоізоляції. Одним з таких будівельних виробів $є$ композиційний будівельних матеріал - структурна ізольована панель 3D (CIП).

У статті обгрунтована можливість використання сучасних структурних ізольованих панелей для цілей енергозбереження. Висвітлено основні технічні характеристики і особливості 3D-панелей, наведені показники, що підтверджують актуальність використання даної технології в поєднанні із застосуванням рекуператорів в будівництві. Деталізована основна структура пристрою СІП-панелей. Виділено переваги та недоліки існуючих структурних ізольованих панелей, як з питання енергозбереження, так і з особливостей їх застосування в цілому.

Оцінено, що використання СІП може знизити собівартість будівництва в 2 рази. Наприклад собівартість 1 м $^{2}$ загальної площі будинку складає від 80\$, а з повною обробкою може становити $300 \$$ за м². При цьому, за рахунок високих технічних характеристик утеплювача, значно знижуються енерговитрати на опалення.

В результаті проведеного дослідження доведено, що використання технології СІП $є$ вигідним рішенням, адже позитивно впливає на енергоефективність будівлі за рахунок особливостей конструкції. Актуальність монтажу панелей підтверджує той факт, що будівлі, незалежно від призначення, знижують енерговитрати на 65-70\%.

Ключові слова: енергоефективність, паливно-енергетичні ресурси, структурна ізольована панель, 3D-панелі, рекуператор. 


\title{
ПЕРСПЕКТИВНОСТЬ ИСПОЛЬЗОВАНИЯ СТРУКТУРНЫХ ИЗОЛИРОВАННЫХ ПАНЕЛЕЙ 3D ПРИ ВОЗВЕДЕНИИ ЭНЕРГОЭКОНОМИЧНЫХ ЗДАНИЙ И СООРУЖЕНИЙ
}

\author{
${ }^{1}$ Дударь И.Н., д.т.н, профессор, \\ indudar11@gmail.com, ORCID: 0000-0001-8453-7929 \\ ${ }^{1}$ Яворовская О.В., соискатель, \\ olhaiavorov@gmail.com, ORCID: 0000-0002-5304-1389 \\ ${ }^{1}$ Винницикй национальный технический университет \\ ул. Хмельницкое шоссе, 95, г. Винница, 21021, Украина
}

\begin{abstract}
Аннотация. Вопрос энергетической ефективности стоит остро для всех отраслей народного хозяйства еще с начала обретения Украиной независимости. При этом особое внимание уделено вопросам энергосбережения в строительстве и коммунальном хозяйстве города, поскольку именно на города в итоге приходиться более 85\% энергоресурсов. Сложившаяся ситуация является следствием деформированной структуры энергопотребления, использование устаревших технологий в коммунальном хозяйстве, медленного внедрения энергосберегающих мероприятий и технологий, а также отсутствия должной модернизации зданий и сооружений.

Поэтому, сегодня актуален вопрос исследования строительных материалов, которые были бы энергосберегающими, в первую очередь за счет герметизации и теплоизоляции. Одним из таких строительных изделий является композиционный строительных материал - структурная изолированная панель 3D (СИП).
\end{abstract}

В статье обоснована возможность использования современных структурных изолированных панелей для целей энергосбережения. Освещены основные технические характеристики и особенности устройства 3D-панелей, приведены показатели, подтверждающие актуальность использования данной технологии в сочетании с применением рекуператоров в строительстве. Детализирована основная структура устройства СИП-панелей. Показаны преимущества и недостатки существующих структурных изолированных панелей, как по вопросу энергосбережения, так и из особенностей применения в целом.

Оценено, что использование СИП имеет возможность снизить себестоимость строительства в 2 раза. Например себестоимость $1 \mathrm{~m}^{2}$ общей площади дома составляет от 80 \$, а с полной отделкой может составлять $300 \$$ на м². При этом, за счет высоких технических характеристик утеплителя, значительно снижаются энергозатраты на отопление.

В результате проведенного исследования доказано, что использование технологии СИП является выгодным решением, ведь положительно влияет на энергоэффективность здания за счет присущих особенностей конструкции. Актуальность монтажа данных панелей подтверждает тот факт, что здания, независимо от назначения, имеют экономию на энергозатраты 65-70\%.

Ключевые слова: энергоэффективность, топливно-энергетические ресурсы, структурная изолированная панель, 3D-панели, рекуператор.

Стаття надійшла до редакції 24.09.2020 